\section{Australia's Minor Concessions to Japanese Citizens under the White Australia Policy}

\section{TOMOKO HORIKAWA}

The University of Sydney

\section{(D) https://orcid.org/0000-0003-4343-3263}
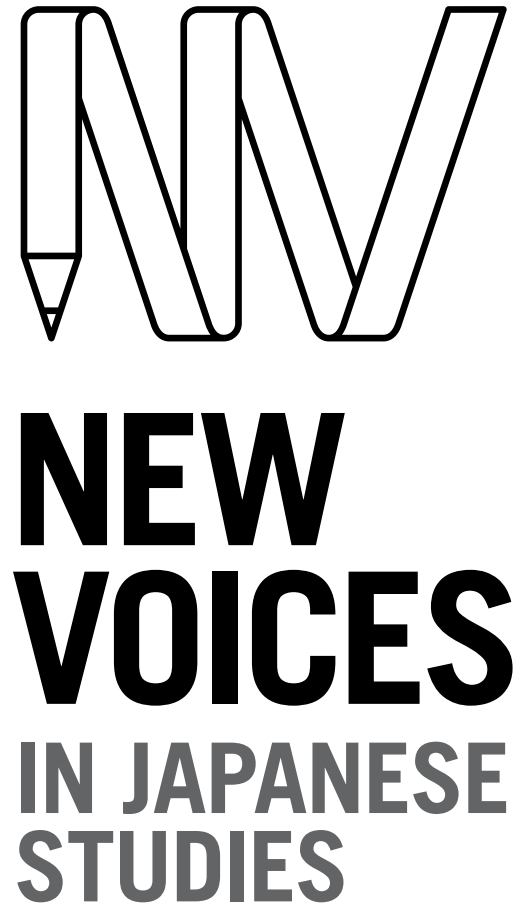

\section{ABSTRACT}

This paper explores concessions made by Australian authorities concerning Japanese immigration during the era of the White Australia Policy in the early twentieth century. Australia's Immigration Restriction Act was introduced in December 1901. As the major piece of legislation in the White Australia Policy, the act made it virtually impossible for non-Europeans to migrate to Australia. However, Japanese people enjoyed a special position among non-Europeans under the White Australia Policy thanks to Japan's growing international status as a civilised power at the time, as well as its sustained diplomatic pressure on Australia. While the Commonwealth was determined to exclude Japanese permanent settlers, it sought ways to render the policy of exclusion less offensive to the Japanese. In the early 1900s, two minor modifications to the Immigration Restriction Act were implemented in order to relax the restrictions imposed on Japanese citizens. Moreover, in the application of Commonwealth immigration laws, Japanese people received far more lenient treatment than other non-Europeans and were afforded respect and extra courtesies by Australian officials. Nevertheless, these concessions Australia made to Japanese citizens were minor, and the Commonwealth government maintained its basic policy of excluding Japanese permanent settlers from Australia. This paper shows that, despite continued diplomatic efforts, Japan was fundamentally unable to change pre-war Australia's basic policy regarding the exclusion of Japanese permanent settlers.

\section{KEYWORDS}

Australia; Australia-Japan relations; history; Immigration Restriction Act; Immigration Restriction Amendment Act; international relations; Japanese immigration; law; Passport Agreement of 1904; White Australia Policy
JAPANFOUNDATION \&

BRINGING JAPAN TO YOU

To link to this article:

https://doi.org/10.21159/nvjs.12.01

New Voices in Japanese Studies is an interdisciplinary, peer-reviewed journal showcasing the work of emerging scholars with ties to Australia or New Zealand and research interests in Japan.

All articles can be downloaded free at newvoices.org.au

(C) The Japan Foundation, Sydney and Tomoko Horikawa, 2020.

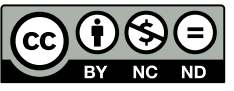

This work is licensed under a Creative Commons Attribution-NonCommercial-
ISSN 2205-3166 NoDerivatives 4.0 International License. 


\section{INTRODUCTION}

Australia's Immigration Restriction Act was introduced in December 1901. It was the major piece of legislation in the now-infamous White Australia Policy, a complex set of legislative and administrative measures aimed at severely restricting non-European immigration to Australia. The act empowered the Commonwealth to exclude all non-European races, including Japanese, from settling in Australia. The introduction of the Immigration Restriction Act provoked strong objections from Japan. The Japanese government noted that the legislation was aimed at excluding races that the Commonwealth government deemed undesirable and was concerned that the Immigration Restriction Act effectively characterised its citizens as such. ${ }^{1}$ Australia was, however, unwavering in its policy of excluding Japanese immigrants.

The strict entry restrictions the White Australia Policy imposed on nonEuropean immigrants are well known. Less well known is the special position that the Japanese enjoyed among non-Europeans under the White Australia Policy. Although the Commonwealth was determined to prevent the Japanese from settling permanently in Australia, Japan's international status as a civilised power in the early twentieth century and its sustained diplomatic pressure on Australia led the Commonwealth to make some concessions and relax the restrictions imposed on Japanese citizens. This paper explores the concessions made by the Commonwealth to the Japanese government and its citizens during the era of the White Australia Policy.

Research into Japanese immigration to Australia under the White Australia Policy in the field of diplomatic history remains limited. Although both the White Australia Policy and Japanese migration are widely and thoroughly researched subjects of historical study, the two literatures are largely distinct. While the existing literature on the White Australia Policy generally examines the domestic origins and development of the policy (e.g., Markus 1979, 1994; Price 1974; Willard 1923), the literature on Japanese migration focuses to a large extent on Japanese immigration to North America (e.g., Asada 1973; Minohara 2002). As a result, the number of studies on Japanese immigration to Australia is small. Moreover, those studies which have examined Japanese immigration to Australia have approached the subject mostly from social and cultural perspectives, depicting the lives and experiences of Japanese immigrants in white Australia (e.g., Sissons 1977a, 1977b, 1979; Nagata 1996; Tamura 2001). Within this context, there are few studies of Japanese immigration under the White Australia Policy in the field of diplomatic history. This situation might be due to the disinclination of political and diplomatic historians to pay sustained attention to immigration issues. To borrow the words of Toshihiro Minohara (2002), immigration is "unfamiliar (馴染夕にくい)” territory for most diplomatic historians, given their traditional focus on national interests and power (5). Or, as Sean Brawley (1995) has put it, "immigration and foreign relations have rarely met in any comprehensive historical analysis" (2). 
That said, there are a few existing studies which have examined the White Australia Policy's impact on Japanese-Australian diplomatic relations, including the work of D. C. S. Sissons, A. T. Yarwood and Isami Takeda. While many of Sissons' works adopt cultural and social perspectives, some of his studies, including "The Immigration Question in Australian Diplomatic Relations with Japan, 1875-1919" (1971) and "Immigration in AustraliaJapanese Relations, 1871-1971" (1972), discuss Japan's reaction to the White Australia Policy and its impact on bilateral Japanese-Australian diplomacy. The development of the White Australia Policy and the mechanism of Asian exclusion is the primary focus of Yarwood's book, Asian Migration to Australia: The Background to Exclusion, 1896-1923 (1964). However, the chapters on Japanese immigration provide a detailed account of JapaneseAustralian diplomatic negotiations surrounding Japan's objection to Australia's racially discriminatory immigration legislation. Similarly, Isami Takeda's 1981 study on the establishment of the White Australia Policy and Australia's dealings with Japan in that context examines the Japanese government's strong objection to the White Australia Policy.

This paper builds upon these studies of Japanese immigration under the White Australia Policy in the field of diplomatic history. However, in contrast to existing studies in this area which mainly discuss the JapaneseAustralian diplomatic confrontation over the White Australia Policy, this paper will explore the Commonwealth's conciliatory attitude to the Japanese government and its citizens. It examines the Japanese-Australian negotiations which resulted in Australia's concessions regarding Japanese immigration, and investigates the nature of these concessions. In so doing, it aims to shed new light on the issue of Japanese exclusion under the White Australia Policy and contribute to the existing literature on Japanese immigration and the White Australia Policy.

\section{JAPAN'S OBJECTIONS TO THE WHITE AUSTRALIA POLICY}

The White Australia Policy comprised multiple pieces of legislation aimed at excluding non-Europeans from permanent settlement in Australia. In addition to the Immigration Restriction Act of 1901, other legislative measures aimed at formalising this exclusion included the Pacific Island Labourers Act of 1901, the Commonwealth Franchise Act of 1902 and the Naturalisation Act of 1903. ${ }^{2}$ The White Australia Policy was born out of the desire of Australians to create a racially and culturally homogenous white British nation. ${ }^{3}$ This desire was inspired by Australians' strong identification with British race and culture and was further strengthened by Australia's unique geo-cultural circumstances. ${ }^{4}$ As the inhabitants of a white British colonial outpost in the Pacific surrounded by people of different cultures and races, many Australians felt that they were in a vulnerable position and feared that Asia's vast population was ready to swamp their big uncultivated land (Meaney 1999, 16; Tavan 2005, 20-21). In

2 The Pacific Island Labourers Act of 1901 stipulated that no Pacific Island labourers would be allowed to enter Australia after 31 March 1904 and that a majority of Islanders living in Australia at the time would be deported from 31 December 1906. The Commonwealth Franchise Act of 1902 disqualified non-Europeans from voting, while the Naturalisation Act of 1903 prevented non-Europeans from applying for naturalisation. 
other words, the White Australia Policy was a product of Australian people's determination to preserve their nation's white British character in the face of perceived threat from their Asian neighbours.

The Immigration Restriction Act was the first major piece of Commonwealth legislation in the White Australia Policy and was its central practical instrument. The Immigration Restriction Act was intended "to place certain restrictions on immigration and to provide for the removal from the Commonwealth of prohibited immigrants" (Federal Register of Legislation, Immigration Restriction Act 1901). However, the Immigration Restriction Act neither mentioned White Australia nor nominated non-Europeans as "prohibited immigrants". This was mainly due to diplomatic pressure applied by Britain and Japan urging Australia not to introduce legislation of an overtly discriminatory character (Jupp 2002, 8; Tavan 2005, 10). Instead, the restrictions were enforced through the application of a dictation test in a European language. According to Section 3(a) of the Immigration Restriction Act, "any person who when asked to do so by an officer fails to write out at dictation and sign in the presence of the officer a passage of fifty words in length in a European language directed by the officer" would fall into the prohibited category (Federal Register of Legislation, Immigration Restriction Act 1901). It was widely understood, though nowhere stated in the act, that the test would apply only to non-European immigrants and it should be in a language not known to the immigrants, thus making it virtually impossible for non-Europeans to migrate to Australia (Jupp 2002, 8-9).

Although the introduction of the Immigration Restriction Act symbolised the formal establishment of the White Australia Policy, White Australia was, in fact, already well accepted as a policy ideal by the time of federation, and a series of colonial laws which were already in place before 1901 attest to this. The origins of the White Australia Policy can be traced to the late 1850s and early 1860s, when the arrival of thousands of Chinese on the Victorian and New South Wales goldfields ignited fear and resentment among white miners toward industrious Chinese diggers and led these colonies to restrict Chinese immigration. In 1855, Victoria passed an act limiting the number of Chinese each vessel landing in Australia could carry, and imposed a landing tax of 10 pounds on every Chinese entering the colony. South Australia passed a similar act in 1857, and New South Wales followed in 1861 (Willard 1923, 21-35; Markus 1979, 25-33). In the mid-1870s, Queensland enacted legislation to deal with a large influx of Chinese miners following the discovery of gold in the north-eastern part of the colony. In 1876, the Goldfields Amendment Act was passed in order to restrict Chinese access to the goldfields (Willard 1923, 50-51). Throughout the 1880s, antipathy towards Chinese immigration in Australia kept growing, and at the Intercolonial Conference of 1888, the Australian colonies agreed to take a uniform stand to severely restrict Chinese immigration. This led immediately to the adoption of legislation against the Chinese in all of the colonies except for Tasmania (Willard 1923, 89-94; Price 1974, 186-98).

It is important to note that during this initial phase of the White Australia Policy, the Chinese were its sole focus and Japanese immigration was not 
the main concern of the colonial authorities. This was mainly because the Japanese population in Australia at the time was much smaller than the Chinese population. ${ }^{5}$ During the 1880 s and the 1890 s, a sizeable number of Japanese labourers started working in the pearling and sugar industries in North Queensland and along the northwest coast of Australia, and the Japanese presence in these areas had caused public agitation in local communities (Sissons 1971, 25; Meaney 1999, 53). However, the Japanese presence in Australian cities was limited as the vast majority of Japanese were in remote tropical locations, engaged in occupations which were considered unsuitable for white labourers. As a result, until the mid-1890s, there was no widespread anti-Japanese sentiment or movement among the broader white Australian population (Takeda 2000, 64).

The Anglo-Japanese Treaty of Commerce and Navigation, which was signed in London on 16 July 1894, brought the question of Japanese immigration to the forefront of Australian anxieties. The treaty, while offering reciprocal tariff preferences, granted reciprocal rights of travel and residence to the signatory nations and their territories, of which Australia was one. The Australian colonies were suddenly faced with a possible influx of Japanese immigrants to Australia. Their anxieties about Japan were further enhanced by the news of Japan's victory over China in the Sino-Japanese War in April 1895. Japan's defeat of China and its subsequent rise to the status of pre-eminent Asian power made the Australian colonies realise that Japan would be a force to be reckoned with politically and led them to view Japan as the primary threat from Asia (Yarwood 1964, 7-8).

However, the Anglo-Japanese commercial treaty of 1894 was not immediately binding on the Australian colonies. Article 19 stipulated that the treaty was not to apply to Britain's self-governing colonies unless they expressed their intention to adhere within two years from the date of its ratification. At the Intercolonial Conference of 1896, the Australian colonies unanimously decided not to adhere to the treaty, rejecting the prospect of increased bilateral trade. Moreover, the delegates at the conference endorsed a proposal to extend their colonies' existing anti-Chinese legislation to all non-European races (Willard, 1923, 109-110; Takeda, 1981, 23-25). Subsequently, New South Wales, South Australia and Tasmania introduced the Coloured Races Restriction and Regulation Bills, which restricted the entry of non-European races into these colonies (Willard 1923, 110).

The introduction of these bills by the Australian colonies angered the Japanese authorities. In his letters to British Foreign Secretary Lord Salisbury, the Japanese minister in London, Takaaki Katō, stated that the Japanese government could not accept any legislation which regarded its people as being on "the same level of morality and civilization as Chinese and other less advanced populations of Asia" because "Japan is far superior to other Asian nations" (NGB 1897, 605-09, 619-22). This claim that Japan was a civilised nation superior to China and other Asian nations was made repeatedly by the Japanese government during the late nineteenth and early 
twentieth centuries. This was because achieving equality with the West by attaining a 'civilised' international status was a dominant theme in Japan's foreign policy after the so-called 'unequal treaties' were imposed upon it by Western powers in the mid-1850s. ${ }^{6}$ To this end, Japan, under the slogan of 'abandon Asia, join the West' (脱亜入欧), tried to join the ranks of the more influential European powers by distancing itself from its Asian neighbours (Beasley 1990, 54-120; Jansen 2000, 371-455). ${ }^{7}$ Japan objected to these colonial bills because they put its citizens in the same category as 'uncivilised' Chinese and other Asian peoples, and in doing so signified Japan's inferiority to European nations (Yarwood 1964, 12; Takeda 1981, 31-36). In the end, Britain obstructed these bills by reserving royal assent, and urged the colonies to adopt a less offensive and more indirect method of exclusion in the form of a dictation test (Bennett 1992, 29). ${ }^{8}$ In 1897, Western Australia copied Natal in British South Africa by introducing a dictation test for immigrants. Western Australia was followed by New South Wales in 1898 and Tasmania in 1899 (Jupp 1998, 75). The Japanese government expressed its satisfaction with these colonial laws which adopted an indirect method of exclusion and did not explicitly signify Japan's inferiority to European nations, commenting that they would not bring “dishonour (污辱)" to Japanese people (NGB 1898, 95).

On 1 January 1901, the Australian colonies federated to become the Commonwealth of Australia. The Immigration Restriction Act was the first major piece of legislation introduced by the newly formed Commonwealth Parliament in June. The Japanese government, again as in the late colonial period, insisted that the legislation should not classify its people together with Chinese or other Asian people. As mentioned earlier, Section 3(a) of the Immigration Restriction Act required prospective immigrants to Australia to take a dictation test in a European language. Japan strongly opposed this provision because it failed to treat Japanese people "in the same manner as" European people (NGB 1901, 827). In a letter to Australian Prime Minister Edmund Barton, the Japanese consul in Sydney, Hisakichi Eitaki, insisted that "the Japanese belong to an Empire whose standard of civilization is so much higher than that of Kanakas, Negroes, Pacific Islanders, Indians, or other Eastern peoples" (NAA: A8, 1901/203/1; NGB 1901, 791-92). ${ }^{9} \mathrm{He}$ repeatedly urged the Commonwealth to enter into an agreement with Japan on immigration in order to exempt Japanese citizens from the terms of the Immigration Restriction Act (NGB 1901, 791-92, 822-23). The Japanese government also appealed for British intervention and requested the British government to induce the Commonwealth to modify the Immigration Restriction Act in such a manner "as to place Japanese on an equal footing

6 In 1858, Townsend Harris, the American consul in Japan, persuaded Japan to sign the Treaty of Amity and Commerce, which would open five ports between 1859 and 1863 to American residence and trade. This treaty contained two critical unequal measures: tariff restrictions and extraterritoriality. Soon the principal European powers followed suit with similar treaties. Through these treaties and subsequent agreements, the full 'unequal treaty system' developed between the European powers and China was applied to Japan, and Japan was stripped of its sovereign prerogatives. For a discussion of the unequal treaties imposed on Japan by Western powers, see Beasley 1990, 26-34. For a discussion of Japan's attempt to achieve equality with the West by attaining a civilised international status, see Suzuki 2005 and 2009.

7 This slogan became popular after the publication of Yukichi Fukuzawa's widely noted article, 'Leaving Asia' (脱覀論), in the Japanese newspaper Jiji Shimpō on 16 March 1885.

8 This was partly due to Japan's strong objection to these colonial bills. At the same time, Britain did not want any legislation which overtly discriminated against the Empire's people of colour, particularly Indians. See Bennet 1992, 29.

9 In early 1896, Japan opened its first Australian consulate in Townsville, and in April, Tsunejirō Nakagawa was appointed as the first Japanese consul in Australia. In the following year, the second Japanese consulate in

Tomoko Horikawa New Voices in Japanese Studies, Vol. 12, 2020, pp. 1-20 
with European immigrants" or else to reserve royal assent to the act (NGB 1901, 853). In spite of Japan's persistent efforts, the Immigration Restriction Act passed both Houses of the Commonwealth Parliament without exemptions for Japanese citizens and received royal assent on 23 December 1901.

Even after the Immigration Restriction Act became law, Japan continued its efforts to prevent the act from being applied to its citizens, pressing the Commonwealth to afford its citizens special treatment and exempt them from the legislation. However, Prime Minister Barton almost completely ignored Japan's repeated approaches and showed little inclination to listen to, let alone comply with, Japan's requests and remonstrations (see NGB 1902, 701-59). As a result, Japan was unable to gain any concessions regarding restriction on the entry of its citizens into Australia. ${ }^{10}$ However, this changed soon after Alfred Deakin became prime minister in September 1903.

\section{THE PASSPORT AGREEMENT OF 1904}

Alfred Deakin became prime minister of the Commonwealth of Australia on 24 September 1903, after having taken over leadership of the Protectionist Party from Edmund Barton, who had retired to become one of the founding justices of the High Court. The arrival of Deakin spelt a change in Commonwealth policy regarding the entry of Japanese citizens. In contrast with Barton, who had maintained an uncompromising attitude toward Japan's continued approaches and protests, Deakin was prepared to resolve Japanese immigration issues.

In September 1901, during parliamentary debates on the Immigration Restriction Act, Deakin made a statement which displayed the high regard he held for Japan. Although Deakin claimed that "the Japanese require to be absolutely excluded [from entry to Australia]", he conceded that "a nation which is capable of the achievements which Japan is able to exhibit artistically, politically, and of the industrial expansion now going on in that country, is justified in resenting...any unnecessary reflection upon its character by another nation" (CPD, House of Representatives 1901, No 37, 4812). Deakin thus insisted that "when it becomes necessary for us to exclude people like the Japanese it is reasonable that we should exclude them in the most considerate manner possible, and without conveying any idea that we have confused them with the many uneducated races of Asia and untutored savages who visit our shores" (CPD, House of Representatives 1901, No 37, 4812). These statements

Australia was established in Sydney, and Consul Nakagawa was relocated from Townsville to Sydney to become its first consul. Eitaki succeeded Nakagawa as the Japanese consul in Sydney in January 1899. In 1901, the consulate in Sydney was upgraded to Consulate-General.

10 The only exception was Japanese pearl divers. In 1902, the pearl-shelling industry bases in Thursday Island, Darwin and Broome became the sole exceptions to the policy of excluding indentured coloured labour. The objection that the practice violated the principle of the White Australia Policy was raised and royal commissions were ordered by the Queensland and the Commonwealth governments. However, the investigators at Thursday Island and Broome reported that owners of pearl luggers would be ruined if they had to pay the high wages necessary to attract white men to the work and recommended that exemptions be granted from the dictation test to allow the introduction of coloured labourers on condition of compulsory repatriation on expiry of contract (see Yarwood 1964, 96-97). Japanese pearl shell labourers were an important part of the Japanese community in Australia during the era of the White Australia Policy, constituting almost 70 per cent of the total number of Japanese in Australia around 1901. However, the cases of Japanese pearling industry labourers are beyond the scope of this paper. For a detailed discussion of Japanese involvement in the Australian pearling industry in the late nineteenth and early twentieth centuries, see Sissons 1979. 
foreshadowed the policy Alfred Deakin as prime minister would formulate concerning the issue of Japanese immigration. Throughout his term as prime minister, Deakin implemented a series of new policies towards Japan, both at legislative and administrative levels, in order to relax the restrictions imposed on Japanese citizens by the Immigration Restriction Act. The first of these was the Passport Agreement of 1904.

Not long after Deakin took office, the Russo-Japanese War broke out in February 1904. The outbreak of the war prompted Deakin to reassess Australia's standing in relation to Japan. In particular, two letters to Deakin from Dr John Mildred Creed, a member of the Legislative Council of New South Wales, seemed to have imparted some urgency to Deakin's appreciation of the matter (Yarwood 1964, 86-87). Creed's first letter, written shortly before the outbreak of the war on 30 December 1903, began by declaring that the continued exclusion of Japanese citizens under the Immigration Restriction Act was a subject which "must be dealt with in the very near future" in order to ensure Australia's "ultimate safety as a nation". Creed argued that if Japan was victorious in the imminent war with Russia, "her standing among the nations will be so vastly increased that she is not likely to tamely submit to what she considers a national humiliation and what would now be a graceful concession will then possibly have to be yielded to superior force". ${ }^{11}$ In his second letter, written soon after the outbreak of the war and dated 25 March 1904, Creed put forward a suggestion that Japanese of the non-labouring class who had passports issued by their government should be admitted to the Commonwealth. ${ }^{12}$ This letter appears to have been successful in persuading the Deakin government to make some urgent conciliatory measures towards Japan on immigration.

On 16 April 1904, Atlee Hunt, the secretary of the Department of External Affairs, sent a confidential letter to the new acting Japanese consul-general, Kazuo Iwasaki, to ascertain whether his government was still interested in an arrangement such as the former Japanese consul-general Eitaki had proposed to Deakin in October $1902 .{ }^{13}$ In the letter, Hunt suggested that Japanese merchants, students and tourists with passports sufficiently identifying them as such and specifying the purpose and duration of their visits would be allowed to enter Australia on the condition that their document should be examined at the first port of call. He promised that if the Japanese government was amenable to the suggestion, Prime Minister Deakin would frame a formal communication to Iwasaki on the subject (NGB 1904, Vol. 2, 225-27). Iwasaki replied immediately, stating "I shall wait, with much pleasurable anticipation, the promised formal communication from your respected Chief upon this matter" (NGB 1904, Vol. 2, 228). Before this could be done, however, Deakin resigned from his office on 27 April 1904 after the Labor Party withdrew its support over the Conciliation and Arbitration Bill. ${ }^{14}$ Following this, Hunt explained to Iwasaki that under these political circumstances some delay 
would be unavoidable, but promised that the matter would not be overlooked or unduly delayed (NGB 1904, Vol. 2, 228).

Deakin was succeeded by Chris Watson, the leader of the Labor Party, and after a lapse of several months, the question of immigration from Japan was revived towards the end of Watson's short-lived government. On 10 August 1904, William Morris Hughes, the minister for External Affairs, informed Iwasaki that the Commonwealth had decided to allow Japanese merchants, students and tourists to enter Australia temporarily without being subjected to any restriction, provided that their passports specified the purpose and duration of their visits. Hughes explained that on arrival in the Commonwealth, Japanese citizens in these categories would not have to take the dictation test prescribed by the Immigration Restriction Act and that if they wished to stay longer than 12 months, they could lodge an application for a certificate of exemption for the desired term. At the same time, Hughes stressed that the Commonwealth had not abandoned any of its rights under the Immigration Restriction Act and that it preserved control over Japanese passport holders (NGB 1904, Vol. 2, 242-43). As it happened, however, before the agreement was reached with Japan, the Watson government also fell victim to the Conciliation and Arbitration Bill and resigned on 18 August 1904. George Reid, the leader of the Free Trade Party, was sworn in as prime minister, and it then became Reid's responsibility to conclude the agreement with Japan.

The day after Reid took office, on 19 August 1904, he received a letter from Iwasaki stating that Iwasaki had been authorised by the Japanese government to accept the terms and conditions of the proposed agreement. Iwasaki concluded his letter by expressing his hope that "this exemption may be the means of promoting intercourse and improving trade relations between Japan and the Commonwealth of Australia" (NGB 1904, Vol. 2, 243-44). In response, Reid notified Iwasaki that the exemption would take effect from 1 October 1904 (NGB 1904, Vol. 2, 244). Accordingly, the Passport Agreement was concluded between Japan and Australia in October 1904. The agreement allowed Japanese merchants, students and tourists to enter Australia without restriction, as long as their passports specified the purpose and duration of their visits.

The Passport Agreement of 1904 was the first substantial concession the Commonwealth made regarding the entry of Japanese citizens. However, unlike the so-called 'Gentlemen's Agreements' that Japan concluded with the United States and Canada in 1907-08, the Passport Agreement of 1904 granted the Japanese no right of entry for permanent residence. ${ }^{15}$ Furthermore, the Commonwealth had made clear that it preserved all of its rights under the Immigration Restriction Act and that it retained its power over Japanese residents in Australia. Following a year of residence in Australia, a Japanese passport holder could only extend his stay by securing

Commonwealth Conciliation and Arbitration Act 1904, https://www.legislation.gov.au/Details/C1904A00013). When Deakin became prime minister on 24 September 1904, his Protectionist Party did not have a majority in either house and formed government only by means of a coalition with the Labor Party. The Labor Party, in turn, insisted on widening the scope of the legislation, which Deakin found unacceptable. This resulted in the resignation of his cabinet. Ongoing issues surrounding the legislation also resulted in the resignation of the Chris Watson (Labor) and George Reid (Free Trade) cabinets. 
a Certificate of Exemption from the dictation test (CEDT), which in turn could only be renewed annually at the discretion of the Department of External Affairs. In other words, while the Commonwealth tried to pacify the Japanese opposition to the Immigration Restriction Act by affording them an exemption which was not accorded to other non-Europeans, it was determined to maintain the basic principle of the White Australia Policy. ${ }^{16}$

\section{IMMIGRATION RESTRICTION AMENDMENT ACT OF 1905}

Although Australia made some conciliatory moves towards Japan by implementing the Passport Agreement, the Immigration Restriction Act still classified the Japanese in the same category as other non-European people under the terms of the dictation test, which all non-Europeans were required to take in order to gain entry into Australia. Some in Australian political circles started to question the discriminatory treatment that was formalised in the Immigration Restriction Act and its implied inferiority of Japanese people. The most prominent of them was Bruce Smith, a Free Trade Party member from New South Wales. Smith was a vigorous opponent of the Immigration Restriction Act even prior to its enactment and one of the very few members of the House of Representatives who openly voiced opposition to the restrictions placed on entry of the Japanese into Australia. ${ }^{17}$ After the Immigration Restriction Act was introduced, Smith continued to campaign against restricting non-white immigration and pressed for an arrangement with Japan in order to improve commercial and political relations between the two countries (Yarwood 1964, 32).

Towards the end of 1904, Smith submitted a notice of motion to the House of Representatives. In his motion, Smith declared that "the time has arrived for differentiating the Japanese people from other Asiatic races with whom they have been impliedly grouped under the Immigration Restriction Act of 1901" (CPD, House of Representatives 1905, No. 39, 2941). He then proposed to amend the Immigration Restriction Act to either make the admission of Japanese citizens to Australia the subject of mutual arrangement or to include the Japanese language as one of the options for the Immigration Restriction Act's dictation test (CPD, House of Representatives 1905, No. 39, 2942). Australian newspapers reacted favourably to Smith's proposal. The Telegraph in Brisbane, for instance, commented that Smith's motion was "the crystallisation of the feeling of Australia towards Japan at the present day". The newspaper observed that before the outbreak of the Russo-Japanese War, "most Australians looked upon the Japanese as a swarm of coloured aliens of somewhat barbaric instincts", but since the war, the Japanese "have lifted themselves far above the level of all other Asiatic races". It then argued in favour of the proposed amendments, stating that "we do not wish to impose any stigma; we wish to enter into relations of mutual respect with a people

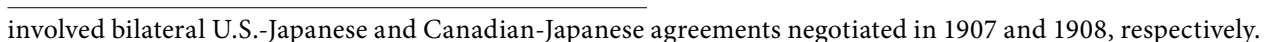
The so-called 'gentlemen's agreement' was Japan's favoured solution for problems concerning restrictions to Japanese immigration. Under this formula, the Japanese government agreed to voluntarily regulate the emigration of its citizens while being afforded most favoured nation treatment regarding right of entry. In this way, Japan sought to maintain the appearance of being accorded equal treatment with European nations. See Sissons 1972, 195; Bennet 1992, 30.

16 Indians were also granted an exemption from the dictation test under the Passport Agreement which was concluded between Australia and India in 1904.

17 See Mr. Bruce Smith, CPD, House of Representatives 1901, No. 39, 5153-67. 
whom the motherland has been fit to accept as an honoured friend and ally" (2 December 1904, 2).

As the above article indicates, Japan's success in its war against Russia made a big impression in Australia. Even before the war was over, newspapers across the country started speculating about how Japan might react to Australia's treatment of Japanese immigrants in the event of its potential victory over Russia. For example, on 29 March 1905, Hobart newspaper The Mercury wrote:

when the war is over, and the rulers of Japan are able to turn their attention to other things, we shall not be surprised if reprisals with Australia are undertaken. Japan will certainly have the right to exclude Australians and their produce, and we cannot expect the Imperial authorities to back up any protest which may be made.

(4)

Melbourne newspaper The Argus, for its part, commented in its editorial on 22 April that "as a great power, admitted into the fraternity of civilised nationsand the result of the war must be to place her in that position-she will need to be approached with a courtesy and a consideration hitherto conspicuous by their absence" $(1905,12)$.

Amid these agitations about Japan's potential reaction to Australia's immigration policy, Deakin commenced his second term as prime minister on 5 July 1905 and immediately returned to the task of removing any possible source of friction with Japan from the Immigration Restriction Act. ${ }^{18} \mathrm{~A}$ little more than a month after resuming office, around the same time as the AngloJapanese Alliance was renewed on 12 August, Deakin sent a confidential memo to Japanese Consul-General Iwasaki in Sydney asking for the Japanese government's suggestions regarding an impending review of the Immigration Restriction Act. At the same time, he insisted that the Commonwealth was not contemplating any change to the basic policy of the Immigration Restriction Act and remained opposed to the admission of permanent settlers from Japan. ${ }^{19}$

On 18 September 1905, shortly after Japan's victory in the Russo-Japanese War on 5 September, Deakin held an interview with Iwasaki, accompanied by Atlee Hunt, the secretary of the Department of External Affairs. At the interview, Deakin raised the possibility of inserting a clause in the Immigration Restriction Act which would have the effect of exempting Japanese citizens from the act. Deakin suggested that the new clause should provide that the Immigration Restriction Act would not apply to the subjects of any nation with which the Commonwealth had made a "treaty" or a "special agreement" on the subject of immigration (NGB 1905, Vol. 2, 256-57). By a "treaty" or a "special agreement", Deakin did not mean the Anglo-Japanese Treaty of

18 The Anglo-Japanese Alliance, which was first signed on 30 January 1902, was renewed and extended twice, in August 1905 and again in July 1911. The alliance committed the two powers to remain neutral in any war fought by the other against a single power in order to preserve the status quo, and to join the other in any war fought against more than one power.

19 According to Yarwood $(1964,89)$, this letter has not survived. However, the letter's existence and content can be deduced from a letter sent by Hunt to Iwasaki on 23 October 1905, and a subsequent letter sent by Iwasaki to Tarō Katsura, prime minister and acting foreign minister of Japan, on 10 November 1905 (NGB 1905, Vol. 2, 
Commerce and Navigation of 1894, which conferred reciprocal rights of travel and residence to the signatory nations and their territories. Instead, he referred to the kind of agreement which had been suggested by the former Japanese Consul Hisakichi Eitaki in his letter to Prime Minister Edmund Barton of 3 May 1901—namely, that Japanese immigration should be regulated by mutual arrangement rather than by race-based immigration restriction legislation (NGB 1905, Vol. 2, 258-60).

However, it seems that there was a misunderstanding in connection with the word "treaty". Contrary to Deakin's intention, Iwasaki came to hope that Australia was prepared to accept the terms and conditions of the 1894 AngloJapanese commercial treaty, just as Queensland had already done (NGB 1905, Vol. 2, 260-61, 264-65). ${ }^{20}$ Deakin, on the other hand, had assumed that the issue might be settled to Japan's complete satisfaction by negotiating a separate reciprocal treaty or agreement on immigration alone. Deakin had believed that a reciprocal arrangement of this nature would remove any suggestion of racial inferiority and could not possibly be offensive to the Japanese government (NGB 1905, Vol. 2, 258-61). However, Deakin had misjudged the affair, as shown when Iwasaki accused Deakin of misleading him (NGB 1905, Vol. 2, 260-61). In response, Hunt refuted Iwasaki's accusation and expressed the Commonwealth's desire to meet Japan's wishes, insofar as they were consistent with the basic policy of the Commonwealth (NGB 1905, Vol. 2, 261-64). After a protracted, sometimes fiery, correspondence between Iwasaki and Hunt regarding this matter, in which neither party was willing to change his position, Iwasaki declared that the negotiation had "failed" (NGB 1905, Vol. 2, 265). In other words, Deakin's offer, which conceded all that Eitaki had asked for in 1901, was not accepted by Japan.

Nevertheless, Deakin went ahead and submitted a draft bill to the House of Representatives on 10 November 1905, which amended the dictation test of the Immigration Restriction Act from "any European language" to "any prescribed language", thereby affording Japanese citizens an appearance of receiving the same treatment as their European counterparts. The draft bill also contained a new addition, Section 4 (a), which provided for the exemption from the dictation test of the citizens of any country with which the Commonwealth had made an arrangement regulating their admission (CPD 1905, No. 45, 4942-46). The Immigration Restriction Amendment Act passed the House of Representatives on 6 December and the Senate on 12 December, and received Royal Assent on 21 December 1905. However, no arrangement for reciprocal entry regulations between Japan and Australia was ever submitted for the approval of the Commonwealth Parliament, as required by the new Section 4 (a). This was primarily due to Japan's consistent refusal of such an arrangement, given that Australia insisted on preserving its unrestricted right to legislate against Japanese immigration and also remained opposed to the admission of permanent settlers from Japan (Yarwood 1964, 89; Frei 1991, 84).

The Immigration Restriction Amendment Act of 1905 was prompted by Japan's rising international status as a result of its victory over Russia in the 
Russo-Japanese War, with the perceived implications of Japan's military success spurring Prime Minister Deakin to attempt to make the White Australia Policy less offensive to the Japanese. By amending the dictation test from "European language" to "any prescribed language", Deakin tried to soften the implication of Japan's inferiority to European nations and grant Japanese immigrants nominal equality with their European counterparts in terms of bureaucratic treatment. Moreover, Deakin was prepared to exempt Japanese citizens of all classes from the dictation test by concluding a bilateral agreement with Japan on immigration. However, in spite of these concessions, he was adamant that the Commonwealth would not join the Anglo-Japanese Treaty of Commerce and Navigation of 1894, which offered Japanese citizens full liberty to enter, travel or reside in any part of the British dominions. In other words, although Deakin was willing to accord the Japanese an appearance of equality with their European counterparts, he was not ready to abandon the policy of restricting Japanese immigration. In this sense, the Immigration Restriction Amendment Act of 1905 was only a minor concession by Australia as it made no difference to the Commonwealth's basic policy of excluding Japanese permanent settlers from Australia.

\section{ADMINISTRATIVE CONCESSIONS}

In addition to implementing the Passport Agreement of 1904 and the Immigration Restriction Amendment Act of 1905, the Commonwealth also tried to make the Immigration Restriction Act less offensive to the Japanese through its administration of immigration laws. Broadly speaking, Japanese living in Australia around this time were subject to two iterations of Commonwealth policy: the state and federal laws themselves, and their selective enforcement by customs and immigration officials, police and bureaucrats in government departments (Oliver 2007, 3-5). Policy administration, which is guided by national interests, is not monolithic. In the case of Japanese immigration, this was particularly noticeable. Japanese people, who were considered to be of "high class" thanks to Japan's international status as a civilised power, received far more lenient treatment than other non-Europeans and were treated with respect and extra courtesies by Australian officials (Oliver 2004, 23; see also Oliver 2007, 4-6).

One incident in particular highlights this point. In February 1904, several months prior to the conclusion of the Passport Agreement with Japan, a Japanese labour inspector named Mr Tabei was travelling in Queensland's sugar plantation district when he was ordered by a tramway guard to move to the special wagon reserved for coloured passengers. R. G. Johnson, the chairman of the Hinchinbrook Shire Council where the incident took place, immediately sent a telegraph to Mr Tabei expressing his regret for what had happened. ${ }^{21}$ However, the Japanese consul in Townsville, Rinzaburō Tayui, complained forcefully to the Hinchinbrook Shire Council, calling the regulations to have a separate car for coloured people "distinctly racial discrimination" (NGB 1904, Vol. 2, 233-34). Tayui also wrote a letter of 
complaint to the chief secretary of Queensland, Sir Arthur Morgan, stating that "my countrymen should be treated more properly in the tramway and that such [a] mistake should not be repeated in future". Tayui requested Morgan to instruct the Hinchinbrook Shire Council to rescind such regulations or at least to exempt Japanese nationals from them (NGB 1904, Vol. 2, 235-36). The shire council immediately decided to withdraw the guidelines stipulating that no coloured people were allowed to ride in the white car (NGB 1904, Vol. 2, 240-41).

However, while issues of this nature were treated with delicacy by local-level authorities, the Commonwealth's restrictions on permanent immigration from Japan remained unchanged. While the Passport Agreement of 1904 did constitute a concession, it was notably structured to ensure that the discretion to admit or reject Japanese immigrants at will remained in the hands of the Commonwealth authorities. In 1910, the Japanese consul-general in Sydney, Kisaburō Ueno, criticised the uncertainty of this system in a letter to the minister for External Affairs, Lee Batchelor. In the letter, Ueno pointed out that the Department of External Affairs seemed to regard five years as the maximum duration of residence for Japanese passport holders. He argued that this practice was "undoubtedly a serious interruption and a great handicap" to the business of Japanese companies based in Australia because it subjected them to "the inconvenience of periodically changing expert and experienced men for novices" (NGB 1910, Vol. 2, 145). Ueno also drew Batchelor's attention to a difference which seemed to exist between the Australian and Japanese interpretations of the term 'merchant'. He stated that in Australia, the term referred only to the principals of wholesale establishments, while in Japan it also meant retailers, clerks, assistants and anyone employed in any department of mercantile business. He insisted that Australian exports to Japan, which were valued at $£ 1,267,963$ in 1908 , required "permanent oversight by resident and responsible managers" with "the help of competent Japanese clerks and assistants". He therefore requested the Department to "remove the limit which appears to have been prescribed to the extensions of exemptions" and "to ensure the definition of the term 'Merchant' more closely approximat[es] that of the Japanese" (NGB 1910, Vol. 2, 144-47).

In his response, the secretary of the Department of External Affairs, Atlee Hunt, declined to promise that Batchelor would carry out Ueno's requests. He stated that it would not be possible for Batchelor "to sanction an interpretation of a term of the agreement which would tend to lessen the power of the Department to control immigration". "As regards the length of the period of residence", continued Hunt, "Mr. Batchelor appreciates the force of reasons sent out in Mr. Ueno's letter but regrets that [he] cannot see his way to remove all restrictions so as to enable one with a passport to remain in Australia indefinitely". Hunt, however, added that "at the same time, he does not propose to hold that 5 years is the utmost limit which can be allowed as the period of a merchant's stay in Australia" and that the Minister would "consider applications on their individual merits" (NGB 1910 Vol. 2, 149-50).

In other words, Hunt alluded that the Department was willing to consider Ueno's requests favourably. Hunt concluded his letter by saying: 
Mr. Batchelor knows that the Consul-General will understand to how large an extent this Department is dependent on the information which he alone is able to supply in these cases and the Minister relies fully on that information having been substantiated by independent inquiry by the Consulate-General before being submitted for his consideration.

(NGB 1910, Vol. 2, 149-50)

This final paragraph of Hunt's letter to Ueno illustrates the character of the relationship and the degree of trust between the Department of External Affairs and the Japanese Consulate-General, in which the Department held the information provided by the consul-general in high regard.

This was indeed the case, as is shown in Pamela Oliver's (2007) study of the Japanese community in Sydney during the period of the White Australia Policy. In 1916, two Japanese men applied for entry permission for their wives. One of the men was a sub-manager of a large Japanese trading firm in Sydney and approached the consul-general. The other, a clerk, applied directly to the Department of External Affairs. The sub-manager was granted permission for his wife to live in Sydney, but the clerk was refused $(2007,5)$. These two cases highlight the importance of consular connection. Indeed, these cases also indicate that the status of the applicants mattered, and Oliver acknowledges that higher-class people received more favourable consideration $(2007,5)$. However, Oliver also discusses the case of a laundry business owner who approached the consul-general and was granted a 12-month CEDT, which demonstrates that consular recommendations, irrespective of the status of the applicants, were a crucial factor in obtaining CEDTs (2007, 5-6). This indicates that the consul-general's endorsement was considered highly by the Department of External Affairs, and that the department was ready to grant entry permissions or extensions of exemptions to Japanese whose applications were supported by the consulate $(2007,5)$.

The importance of consular connection was also displayed in 1918 in an unusual case concerning entry permission for a family member of a Japanese passport holder. Under the Passport Agreement, family members of a Japanese passport holder were admitted into Australia and allowed to remain for so long as the passport holder maintained his residency status (Yarwood 1964, 99-100). Although this provision was understood by the Commonwealth authorities to apply only to a passport holder's wife and children, Shin Inouye, an employee of Mitsui Bussan Ltd., one of the largest Japanese trading firms at the time, attempted to bring his mother to Australia. The manager of the Sydney branch of Mitsui Bussan, Takae Urabe, approached Japanese Consul-General Seizaburō Shimizu and requested him to ask the Commonwealth government to grant Inouye's mother permission to enter Australia (NGB 1918, Vol. 1, 261). In a letter to Atlee Hunt, now secretary of the Department of Home and Territories, Shimizu explained that the word "families" was interpreted somewhat differently in Japan and could refer to children and parents, including a widowed mother, who might otherwise have to remain alone in her own country (NGB 1918, Vol. 1, 262-63). In response, Hunt, while reminding Shimizu that "the arrangement was only intended to apply to the admission of a passport holder's wife and children", 
notified that "no difficulty, however, will be raised in regard to the landing of Mrs. Inouye". He then requested Shimizu to submit a formal application on behalf of Inouye's mother while he was "advising the Customs authorities at Thursday Island and Sydney to regard this lady as coming within the scope of the passport regulations" (NGB 1918, Vol. 1, 264).

In addition to the close relationship between the Japanese Consulate-General in Sydney and the Department of External Affairs (later the Department of Home and Territories), Hunt's personal relationship with the English secretary to the Japanese consul-general, Edward Foxall, also influenced how the Immigration Restriction Act was applied with respect to the Japanese. ${ }^{22}$ This is demonstrated by the following case concerning entry permissions for Japanese domestic servants. In a private letter to Hunt on 8 July 1918, Foxall inquired about the possibility of allowing Japanese servants to enter Australia. Foxall explained that Japanese wives temporarily residing in Australia, particularly those with small children, were in great need of Japanese domestic help. He provided Hunt with a list of twelve families who wished to bring domestic help from Japan, adding that they were all managers or other important business people employed by big Japanese trading companies such as Mitsui Bussan and Kanematsu, and were based in Sydney and Melbourne (NGB 1918, Vol. 1, 256-58). In response, Hunt notified Foxall that the Department of Home and Territories was prepared to grant permission for the admission of Japanese servants in the five Sydney cases where there were small children. However, Hunt commented that "the matter is not without difficulty" and requested Foxall "for the present to limit the arrangement to Sydney" and to ensure that "it should not become generally known in Thursday Island, Cairns, or Broome, as applications from those towns would raise questions of very considerable difficulty". Hunt concluded the letter by asking Foxall to inform him in advance when the five servants were scheduled to arrive so that he might give the necessary instructions to the customs authorities (NGB 1918, Vol. 1, 258-59).

The foregoing discussion illustrates the importance of the close personal relationship and the mutual trust which had developed over the years between Japanese and Australian bureaucrats, and which in turn enabled Japanese citizens to receive lenient and courteous treatment in the application of Commonwealth immigration laws. Practically all the business of the Department of External Affairs and later the Department of Home and Territories with the Japanese was conducted indirectly, through the consulsgeneral, who ensured that their countrymen were treated in a manner deemed appropriate for citizens of a civilised power. Australia, for its part, was aware of Japan's high level of discontent with the White Australia Policy and was willing to comply with Japan's requests as long as they did not conflict with the Commonwealth's basic policy of excluding Japanese permanent settlers. 


\section{CONCLUSION}

This paper has contributed a new perspective to the literature on Japanese immigration and the White Australia Policy by exploring the underresearched issue of Japanese exclusion from pre-war Australia during the era of the White Australia Policy. The Immigration Restriction Act of 1901 placed Japanese people in the same category as other non-European people and closed Australia to permanent settlement by the Japanese. However, Japanese citizens enjoyed certain privileges and special treatments which were not afforded to other non-Europeans under the White Australia Policy. Although the Commonwealth remained determined to exclude Japanese permanent settlers from Australia, it sought in many ways to render the policy of exclusion less offensive to the Japanese. In the early 1900s, two minor modifications to the Immigration Restriction Act were implemented. The first of these, the Passport Agreement, was concluded in 1904. The agreement permitted Japanese merchants, students and tourists to enter Australia temporarily without having to take the dictation test, which was mandatory for all other non-Europeans. In the following year, in 1905, the dictation test was changed so that it was no longer based specifically on a European language, but instead on any prescribed language, thereby granting Japanese immigrants nominal equality with their European counterparts. Moreover, in the administration of Commonwealth immigration laws, Japanese people, who were considered to be of a higher class than other non-European races, received far more lenient treatment than other non-Europeans and were afforded respect and extra courtesies by Australian officials. The conciliatory attitudes displayed by the Commonwealth towards Japanese citizens were prompted by Japan's rising international status as well as continuous diplomatic efforts by the Japanese government. At the same time, these concessions, particularly at administrative levels, were granted thanks to the close and cordial relationship between the Department of External Affairs (later the Department of Home and Territories) and the Japanese Consulate-General in Sydney.

However, it is important to note that the concessions Australia made concerning the entry of Japanese citizens at this time were minor. They only applied to temporary entry and were confined to certain classes of Japanese. Even while offering these concessions, the Commonwealth consistently made clear that none of its rights under the Immigration Restriction Act would be abandoned and that it retained control over Japanese citizens in Australia. In other words, although Japan fought for changes to Australia's immigration regime and achieved some minor concessions thanks to its status as a civilised power, it was unable to change pre-war Australia's basic policy regarding the exclusion of Japanese permanent settlers. 


\section{REFERENCES}

\section{Primary Sources}

\section{Japan}

Nihon gaikō bunsho (NGB) [日本外交文書]

1897; 1898; 1901; 1902; 1904, Vol. 2; 1905, Vol. 2; 1910, Vol. 2; 1918, Vol. 1.

\section{Australia}

Commonwealth of Australia Parliamentary Debates (CPD), House of Representatives 1901, No. 37, 12 September 1901.

1901, No. 39, 25 September 1901.

1905, No. 39, 28 September 1905.

1905, No. 45, 10 November 1905.

National Archives of Australia (NAA)

A8, 1901/203/1: Correspondence with H. Eitaki; Acting Consul General for Japan, with reference to the Immigration Restriction Act, and admission of Japanese subjects.

Australian Government, Federal Register of Legislation

Immigration Restriction Act 1901

https://www.legislation.gov.au/Details/C1901A00017

Commonwealth Conciliation and Arbitration Act 1904

https://www.legislation.gov.au/Details/C1904A00013

\section{Newspapers and periodicals}

The Argus, Melbourne, March 17, 1904; April 22, 1905.

The Daily Telegraph, Sydney, 23 April, 1904.

The Mercury, Hobart, March 29, 1905.

The Telegraph, Brisbane, December 2, 1904.

\section{Secondary Sources}

Asada, S. [麻田 貞雄]. 1973. “Nichibei kankei to imin mondai [日米関係と移民問題].” In Demokurashii to nichibei kankei [デモクラシーと日米関係], edited by M. Saitō [斎藤 真], 162-210. Tokyo: Nan'undō [南雲堂].

Beasley, W. G. 1990. The Rise of Modern Japan. Tokyo: Charles E. Tuttle Company.

Bennett, N. 1992. “Japanese Emigration Policy, 1880-1941.” In Asians in Australia: The Dynamics of Migration and Settlement, edited by C. Inglis, S. Gunasekaran, G. Sullivan and C. Wu, 23-43. Singapore: Institute of Southeast Asian Studies. https://doi.org/10.1355/9789814379502-005.

Brawley, S. 1995. White Peril: Foreign Relations and Asian Immigration to Australasia and North America, 1919-1978. Sydney: UNSW Press. 
Frei, H. 1991. Japan's Southward Advance and Australia: From the Sixteenth Century to World War II. Honolulu: University of Hawai' i Press.

Jansen, M. 2000. The Making of Modern Japan. Cambridge Massachusetts: Harvard University Press.

Jupp, J. 1998. Immigration. 2nd edition. Melbourne: Oxford University Press.

. 2002. From White Australia to Woomera: The Story of Australian Immigration. Cambridge: Cambridge University Press.

Markus, A. 1979. Fear and Hatred: Purifying Australia and California, 1850-1901. Sydney: Hale and Ironmonger.

1994. Australian Race Relations, 1788-1993. Sydney: Allen and Unwin.

Meaney, N. 1999. Towards a New Vision: Australia and Japan through 100 Years. Sydney: Kangaroo Press.

2001. "Britishness and Australian Identity: The Problem of Nationalism in Australian History and Historiography." Australian Historical Studies 32 (116): 76-90. https://doi.org/10.1080/10314610108596148.

. 2003. "Britishness and Australia: Some Reflections." The Journal of Imperial and Commonwealth History 31 (2): 121-35. https://doi.org/10.1080/ 03086530310001705636.

Minohara, T. [䇾原 俊洋]. 2002. Hainichi iminhō to nichibei kankei [排日移民法と日米 関係]. Tokyo: Iwanami Shoten [岩波書店].

Nagata, Y. 1996. Unwanted Aliens: Japanese Internment in Australia. St Lucia: University of Queensland Press.

Oliver, P. 2004. Allies, Enemies and Trading Partners: Records on Australia and the Japanese. Canberra: National Archives of Australia.

2007. "Japanese Relationships in White Australia: The Sydney Experience to 1941.” History Australia 4 (1): 05.1-05.20.

Price, C. 1974. The Great White Walls are Built: Restrictive Immigration to North America and Australia 1836-1888. Canberra: Australian Institute of International Affairs in association with Australian National University.

Sissons, D. C. S. 1971. "The Immigration Question in Australian Diplomatic Relations with Japan, 1875-1919." Paper presented to the Australian and New Zealand Association for the Advancement of Science, 43rd Congress, Brisbane.

. 1972. "Immigration in Australian-Japanese Relations 1871-1971." In Japan and Australia in the Seventies, edited by J. A. Stockwin, 193-210. Sydney: Angus and Robertson. 
1977a. "Karayuki-San: Japanese Prostitutes in Australia 1887-1916 - Part I." Historical Studies 17 (68): 323-41. https://doi.org/10.1080/10314617708 595555.

. 1977b. "Karayuki-San: Japanese Prostitutes in Australia 1887-1916 - Part II." Historical Studies 17 (69): 474-88. https://doi.org/10.1080/10314617708 595566.

. 1979. "The Japanese in the Australian Pearling Industry." Queensland Heritage 3 (10): 8-27.

Suzuki, S. 2005. “Japan's Socialization into Janus-Faced European International Society." European Journal of International Relations 11 (1): 137-64. https:// doi.org/10.1177/1354066105050139.

2009. Civilization and Empire: China and Japan's Encounter with European International Society. New York: Routledge.

Takeda, I. [竹田 いさぬ]. 1981. “Hakugō seisaku no seiritsu to nihon no taiō: kindai osutoraria no tainichi kihon seisaku [白豪政策の成立と日本の対応：近代才一 ストラリアの対日基本政策].” Kokusai seiji [国際政治] 68: 23-43.

2000. Monogatari Ōsutoraria no rekishi: tabunka midoru pawā no jikken [物語オーストラリアの歴史：多文化ミドルパワーの実験]. Tokyo: Chūkō Shinsho [中公新書].

Tamura, K. 2001. Michi's Memories: The Story of a Japanese War Bride. Canberra: Pandanus Books.

Tavan, G. 2005. The Long Slow Death of White Australia. Carlton North, Victoria: Scribe Publications.

Willard, M. 1923. History of the White Australia Policy to 1920. Melbourne: Melbourne University Press.

Yarwood, A. T. 1964. Asian Migration to Australia: The Background to Exclusion, 1896-1923. Melbourne: Melbourne University Press. 